\title{
High prevalence of anti-SARS-CoV-2 lgG antibody in the Xikrin of Bacajá (Kayapó) indigenous population in the brazilian Amazon
}

\author{
Eliene Putira Sacuema Rodrigues', Isabella Nogueira Abreu², Carlos Neandro Cordeiro Lima², \\ Dennyson Leandro Mathias da Fonseca', Sávio Felipe Gomes Pereira ${ }^{3}$, Laena Costa dos Reis ${ }^{4}$, \\ Izaura Maria Vieira Cayres Vallinoto ${ }^{2}$, João Farias Guerreiro ${ }^{1 \dagger}$ and Antonio Carlos Rosário Vallinoto ${ }^{2^{*}+}$
}

\begin{abstract}
The COVID-19 pandemic caused by Severe Acute Respiratory Syndrome Coronavirus 2 (SARS-CoV-2) reached the Brazilian Amazon and spread among indigenous populations. In the present study, we demonstrate a high prevalence of infection among the Xikrin of Bacajá people (Kayapó). A sample of 100 individuals of both sexes (51 men and 49 women) with ages ranging from 2 to 82 years were clinically evaluated and tested for the presence of anti-SARS-CoV-2 lgG antibody. Among all investigated individuals, 58 were lgG-reactive (58\%) by a rapid test, and $73(73 \%)$ were reactive in an enzyme-linked immunosorbent assay, with no difference between sexes. Oxygen saturation ranged from 82 to $99 \%$, with the lowest value observed in a two-year-old girl. The results show that as expected, SARS-CoV-2 infection rapidly reached more than $70 \%$ of the population, most likely because of the difficulties of maintaining social distance due to cultural characteristics. These results highlight the importance of indigenous health policies as a means of minimizing the impact of the pandemic on these communities.
\end{abstract}

Keywords: COVID-19, Xikrin, Indigenous peoples, Amazonia

\section{Background}

After the identification of the new Severe Acute Respiratory Syndrome Coronavirus 2 (SARS-CoV-2) and the first cases of Coronavirus Disease 2019 (COVID-19) in Wuhan, China, in November 2019, the World Health Organization declared a pandemic alert to all nations [1], increasing concern among health authorities regarding the possible impact of the pandemic if it reached

\footnotetext{
* Correspondence: vallinoto@ufpa.br

†João Farias Guerreiro and Antonio Carlos Rosário Vallinoto are co-senior authors.

${ }^{2}$ Laboratório de Virologia, Instituto de Ciências Biológicas da Universidade Federal do Pará, Belém, PA, Brasil

Full list of author information is available at the end of the article
}

vulnerable populations, such as the indigenous peoples of the Brazilian Amazon [2, 3].

Vulnerability to new infectious agents has been attributed to indigenous peoples because of the characteristics of their genetically controlled immunological response to infections $[4,5]$. In addition, we do not know whether these groups may be more vulnerable to SARS-CoV-2 infection in the presence of other coinfections and pre-existing conditions, such as obesity and malnutrition $[4,6]$.

Recently, our group published a warning about the importance of conducting seroepidemiological surveillance studies in indigenous, riparian, and quilombola communities of the Brazilian Amazon [4] because these populations are characterized by distinct cultural and health aspects that may affect the spread dynamics of SARS- 
CoV-2. Thus, we started a seroepidemiological surveillance study in indigenous communities of the state of Pará (Northern Brazil) to evaluate the seroprevalence of anti-SARS-CoV-2 antibodies in these communities and the impact of the virus on the collective health of these peoples.

\section{COVID-19 in the xikrin of Bacajá village}

With the help of a multidisciplinary health team from the Health Department of the State of Pará (Secretaria de Saúde do Estado do Pará - SESPA) and the Special Indigenous Health District of Altamira (Distrito Sanitário Especial Indígena de Altamira - DSEI-Altamira) of the Special Secretariat of Indigenous Health (Secretaria Especial de Saúde Indígena - SESAI-MS), we evaluated the prevalence of anti-SARS-CoV-2 IgG antibodies using a rapid test (lateral flow method; Guangzhou Wondfo Biotech Co., China) and an enzyme-linked immunosorbent assay (ELISA; Anti-SARS-CoV-2 S1 IgG, Euroimmun, Brazil) in the Xikrin of Bacajá indigenous population (Kayapó), Mebengokré linguistic group of the Macro-Jê linguistic trunk, located on the left margin of the middle Bacajá River (Fig. 1), a tributary of the right margin of the Xingu River, between the municipalities of São Félix do Xingú and Senador José Porfírio, Pará state, Brazil. The present study was approved by the leaders of the Xikrin people and by the National Research Ethics Committee (Comissão Nacional de Ética em Pesquisa CONEP) (CAAE: 33470020.0.1001.0018). The visit to the community occurred in September, when the population was experiencing active cases of COVID-19.

A sample of 100 individuals from the Kenkrô, Bacajá, Pykatum, Moinorô, Mrotidjam, and Pytako villages of both sexes (51 men and 49 women) with ages ranging from 2 to 82 years (mean 27.9) were clinically evaluated and tested for the presence of anti-SARS-CoV-2 IgG antibody. A total of 58 individuals were IgG-reactive $(58 \%)$ by the rapid test, and $73(73 \%)$ were reactive according to the ELISA, with no significant difference between sexes (men [54.2\%] and women [45.8\%]; $p=$ 0.5672 ). The seroprevalence rates among the villages according to the ELISA were as follows: Pykatum $(0 \%$; $0 /$ 4), Bacajá (30.4 \%; 7/23), Kenkrô (90.2\%; 37/41), Mrotidjam villages $(100 \% ; 1 / 1)$, Moinorô $(100 \% ; 13 / 13)$, and Pytako $(100 \%$; 19/19). The mean age of seropositive individuals was 23.9 years, and the mean age of seronegative individuals was 40.5 years. Oxygen saturation ranged from 82 to $99 \%$ (mean $97.8 \%$ ), and the lowest value was observed in a two-year-old girl. The heart rate ranged from 54 to $127 \mathrm{bpm}$ (mean $80.3 \mathrm{bpm}$ ).

Most individuals who were seropositive for IgG (79.5\%) reported no symptoms associated with COVID19. Among the 15 individuals who were symptomatic (20.5\%), the main symptoms reported were cough, dyspnea, fatigue, diarrhea, ear pain, headache, and chest and back pain. Only one death, a 34-year-old man serving as chief (cacique) of the Xikrin people, was recorded among the seropositive individuals within the sample $(1.37 \%$ case fatality rate) during our visit to the Xikrin village.

The body mass index (BMI) of the population ranged from 13.3 to $18.3 \mathrm{~kg} / \mathrm{m}^{2}$ in children aged 0 to 10 years $\left(\right.$ mean $\left.=16.6 \mathrm{~kg} / \mathrm{m}^{2}\right)$; from 18.9 to $29.1 \mathrm{~kg} / \mathrm{m}^{2}$ in young adults $\left(\right.$ mean $\left.=23.2 \mathrm{~kg} / \mathrm{m}^{2}\right)$, and from 20.3 to $34.5 \mathrm{~kg} / \mathrm{m}^{2}$ in adults $\left(\right.$ mean $=25.7 \mathrm{~kg} / \mathrm{m}^{2}$ ). The only case of malnutrition occurred in a five-year-old child $\left(13.3 \mathrm{~kg} / \mathrm{m}^{2}\right)$ who was nonreactive for anti-SARS-CoV-2 IgG. Four cases of obesity were observed, including one child (four years old) seronegative for IgG and three adults reactive for IgG (one man [aged 50 years] and two women [aged 20 and 33 years]).

Regarding coinfection, human T-lymphotropic virus type 2 (HTLV-2) is hyperendemic in the Xikrin population, with prevalence rates above $30 \%$ [7]. The presence of this retrovirus in the coinfection condition has been implicated as a modulating factor of other infections, such as those caused by the hepatitis B (HBV) and C $(\mathrm{HCV})$ viruses [8]; however, in the case of SARS-CoV-2, no data indicate possible modulation of COVID-19 due to HTLV-2/SARS-CoV-2 coinfection.

In addition to the presence of coinfections, other social and environmental factors, such as a lack of drinking water and malnutrition, may impact the spread and severity of COVID-19 in indigenous populations [4]; notably, however, in the Xikrin population, only one case of malnutrition and four cases of obesity were observed, which may be factors associated with the higher number of asymptomatic and mild cases of COVID-19; only one death was recorded in the village.

The results show that as expected, SARS-CoV-2 infection quickly reached $73 \%$ of the population, suggesting that the population would have achieved herd immunity $[4,9]$. We speculate that this rate is most likely a consequence of the difficulties of maintaining social distance due to cultural characteristics, such as different families residing in the same maloca (indigenous home). Additionally, according to personal information provided by an SESAI health care staff member during the visit, some members of the community had traveled to neighboring villages with cases of COVID-19, allowing the virus to be introduced to the village after these individuals returned. The high prevalence observed in the Xikrin village was also reported in Manaus, the capital of Amazonas state, where $76 \%$ of the population had detectable IgG antibodies in October [10]. On the other hand, the seroprevalence of anti-SARS-CoV-2 antibodies measured by rapid tests in 132 Brazilian cities in the months of May and June showed percentages that varied from 0 to $25.4 \%$ [11], which highlights the heterogeneity 


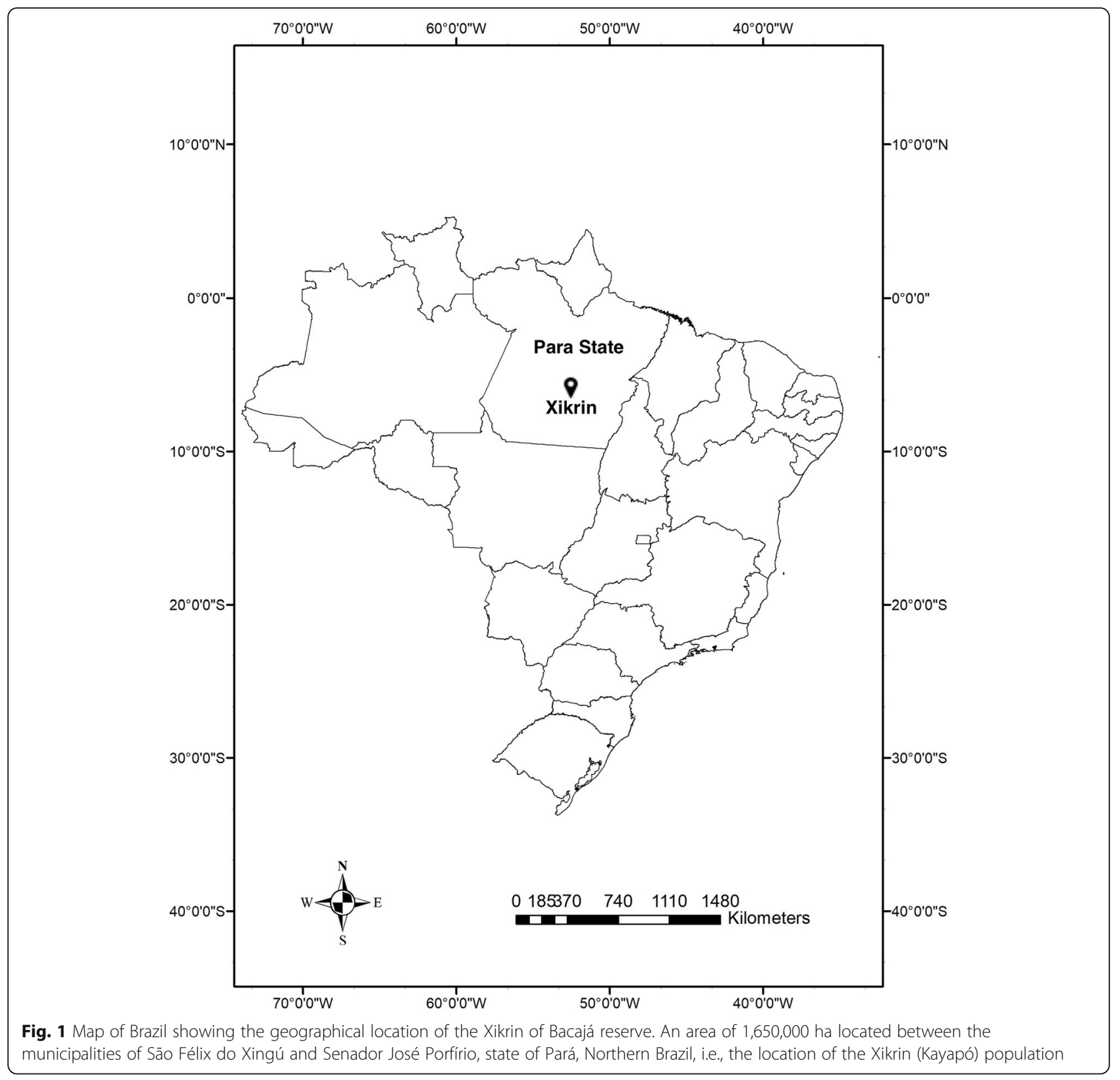

of the pandemic in the Brazilian territory, reinforcing the speed at which the pandemic can reach indigenous populations in the Amazon due to their sociocultural and demographic characteristics, which expose these communities to rapid spread of the virus.

Notably, the present study used both rapid tests and ELISAs for antibody detection; based on the results of some studies, the rapid test has low sensitivity depending on the time of infection and may yield false-negative results as well as false-positive results due to crossreaction $[12,13]$. In addition, examination of the kinetics of the appearance of anti-SARS-CoV-2 antibodies has revealed the absence of seroconversion or even the loss of antibodies after infection [12, 14, 15]. Thus, we selected a method with greater sensitivity and specificity-ELISA - to more accurately detect the prevalence of anti-SARS-CoV-2 IgG antibody in the Xikrin people, which was found to be even higher according to this assay compared to the rapid test.

\section{Conclusions}

In conclusion, the results presented here reinforce the importance of seroepidemiological surveillance studies, which we suggested previously [4], especially studies using methods with high sensitivity/specificity to minimize false-negative results. The results also highlight the importance of indigenous health policies as a means of monitoring and minimizing the impact of the 
pandemic on these communities, such as access to diagnosis, drinking water, hygiene materials, and emergency financial aid, through the creation of a national contingency plan for prevention and control of the epidemic in a more up-to-date manner and the establishment of a national vaccination plan that prioritizes indigenous peoples [4]. To the best of our knowledge, no reports are available in the scientific literature on COVID-19 in indigenous Brazilians. Thus, the primary purpose of the present study is to provide the Brazilian government with information on the pandemic among indigenous peoples to enable the development of adequate measures to control the epidemic in Brazilian indigenous communities, especially in the Amazon.

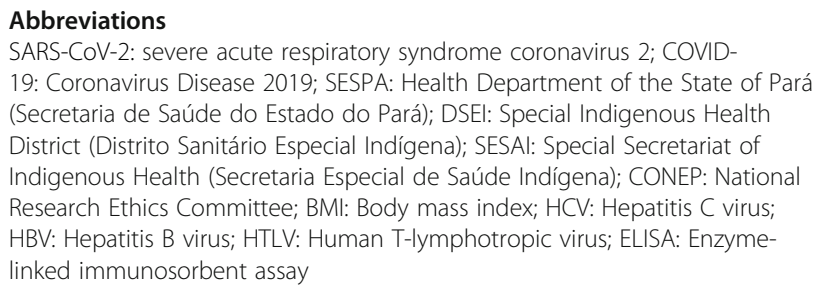

\section{Acknowledgements}

We thank the Xikrin population for authorizing the study and the institutions that provided technical support for the development and implementation of this study.

\section{Authors' contributions}

EPSR wrote the first draft of the article. EPSR, INA, CNCL, DLMF, SFGP, and LCR collected the samples and performed the serological analysis. ACRV, IMVCV, and JFG commented on the draft and approved the final version. All authors approved the final version of the manuscript.

\section{Funding}

This study was supported by the National Council for Scientific and Technological Development (CNPq - 301869/2017-0; MCTIC/CNPq/FNDCT/ MS/SCTIE/DECIT n. 401235/2020-3); Coordination for the Improvement of Higher Education Personnel (CAPES); and Federal University of Pará (UFPAPROPESP/PAPQ-2020).

\section{Availability of data and materials}

Not applicable.

\section{Ethics approval and consent to participate}

The present study was approved by the leaders of the Xikrin people and by the National Research Ethics Committee (Comissão Nacional de Ética em Pesquisa - CONEP) (CAAE: 33470020.0.1001.0018).

\section{Consent for publication}

Not applicable.

\section{Competing interests}

The authors declare no conflict of interest.

\section{Author details}

'Laboratório de Genética Humana e Médica, Instituto de Ciências Biológicas da Universidade Federal do Pará, Belém, PA, Brasil. ² Laboratório de Virologia, Instituto de Ciências Biológicas da Universidade Federal do Pará, Belém, PA, Brasil. ${ }^{3}$ Universidade da Amazônia, Belém, Pará, Brasil. ${ }^{4}$ Programa de Pós-graduação em Enfermagem, Instituto de Ciências da Saúde da Universidade Federal do Pará, Belém, PA, Brasil.
Received: 29 September 2020 Accepted: 19 January 2021

Published online: 28 January 2021

\section{References}

1. World Health Organization. Coronavirus disease (COVID-2019) situation reports; 2020. https://www.who.int/emergencies/diseases/novelcoronavirus-2019/situation-reports/ (accessed on 27 March 2020).

2. Fiocruz. $4^{\circ}$ relatório sobre risco de espalhamento da COVID-19 em populações indígenas. Risco de espalhamento da COVID-19 em populações indígenas: considerações preliminares sobre vulnerabilidade geográfica e sociodemográfica. Available from:https://portal.fiocruz.br/documento/4orelatorio-sobre-risco-de-espalhamento-da-covid-19-em-populacoesindigenas. (accessed 27 June 2020).

3. Amigo I. Indigenous communities in Brazil fear pandemic's impact. Science. 2020:368(6489):352. doi:https://doi.org/10.1126/science.368.6489.352.

4. Vallinoto ACR, da Silva Torres MK, Vallinoto MC, Vallinoto IMV. The challenges of COVID-19 in the Brazilian Amazonian communities and the importance of seroepidemiological surveillance studies. Int J Equity Health 2020;19(1):140. Published 2020 Aug 15. doi:https://doi.org/10.1186/s12939020-01256-7.

5. Zembrzuski VM, Basta PC, Callegari-Jacques SM, Santos RV, Coimbra CEA, Salzano FM, et al. Cytokine genes are associated with tuberculin skin test response in a native Brazilian population. Tuberculosis. 2010;90(1):44-9. doi: https://doi.org/10.1016/j.tube.2009.11.002.

6. Li Y, Sun Y, He J, Zhao P, Luo P, Bai J, et al. Preliminary study on relationships among nutritional risk, serum prealbumin, and peripheral blood T cell subsets in patients with severe COVID-19. Infect Dis 2020;1-3. doi:https://doi.org/10.1080/23744235.2020.1810308.

7. Braço ILJ, de Sá KSG, Waqasi M, Queiroz MAF, Rangel da Silva NA, CayresVallinoto IMV, et al. High prevalence of human T-lymphotropic virus 2 (HTLV-2) infection in villages of the Xikrin tribe (Kayapo), Brazilian Amazon region. BMC Infect Dis. 2019;19(1):459. doi:https://doi.org/10.1186/s12879019-4041-0.

8. Campos KR, Alves FA, Lemos MF, Moreira RC, Marcusso RMN, Caterino-deAraujo A, et al. The reasons to include the serology of human Tlymphotropic virus types 1 and 2 (HTLV-1 and HTLV-2) in the clinical followup of patients with viral hepatitis B and C in Brazil. PLoS Negl Trop Dis. 2020;14(5):e0008245. doi:https://doi.org/10.1371/journal.pntd.0008245.

9. Omer SB, Yildirim I, Forman HP. Herd Immunity and implications for SARSCoV-2 control. JAMA. 2020. Doi:https://doi.org/10.1001/jama.2020.20892.

10. Buss LF, Prete CA Jr, Abrahim CMM, Mendrone A Jr, Salomon T, de AlmeidaNeto $C$, et al. Three-quarters attack rate of SARS-CoV-2 in the Brazilian Amazon during a largely unmitigated epidemic. Science. 2020;8:eabe9728. doi:https://doi.org/10.1126/science.abe9728.

11. Hallal PC, Hartwig FP, Horta BL, Silveira MF, Struchiner CJ, Vidaletti LP, et al. SARS-CoV-2 antibody prevalence in Brazil: results from two successive nationwide serological household surveys. Lancet Glob Health. 2020;8(11): e1390-8. doi:https://doi.org/10.1016/S2214-109X(20)30387-9.

12. Seow J, Graham C, Merrick B, Acors S, Steel KJA, Hemmings O, O'Bryne A, et al. Longitudinal evaluation and decline of antibody responses in SARSCoV-2 infection. MedRxiv 2020.07.09.20148429. doi: https://doi.org/10.1101/ 2020.07.09.20148429.

13. Shibata S, Ishiguro T, Kobayashi Y, Koike M, Numano T, Shimizu Y, et al. High incidence of false-positive results of $\lg \mathrm{G}$ antibody against SARS-CoV-2 with rapid immunochromatographic antibody test due to human common cold coronavirus infection. Respir Med Case Rep. 2020;31:101180. doi:https:// doi.org/10.1016/j.rmcr.2020.101180.

14. Amanat F, Stadlbauer D, Strohmeier S, Nguyen THO, Chromikova V, McMahon M, et al. A serological assay to detect SARS-CoV-2 seroconversion in humans. MedRxiv 2020;2020.03.17.20037713. doi:https://doi.org/10.1101/ 2020.03.17.20037713.

15. Bozkus CC. SARS-CoV-2-specific T cells without antibodies. Nat Rev Immunol. 2020;20(8):463. doi:https://doi.org/10.1038/s41577-020-0393-3.

\section{Publisher's Note}

Springer Nature remains neutral with regard to jurisdictional claims in published maps and institutional affiliations. 